\title{
Sebastian Westcott, the Children of St. Paul's, and Professor Lennam
}

\author{
HERBERT BERRY
}

Professor Trevor Lennam's book, Sebastian Westcott, the Children of St. Paul's, and The Marriage of Wit and Science (Toronto: Univ. of Toronto Press, 1975), is generally about the company of boy actors belonging to St. Paul's Cathedral when Westcott led them, from the 1550 's until 1582. The book does not, however, consist of an argument or development, but of some seven more or less separate parts, some considerable, some quite short, and each with its own virtues and, sometimes, weaknesses. Throughout, Prof. Lennam has done his work carefully: he has gone over it meticulously and has regularly consulted previous work in the subject. But sometimes he has been preoccupied with the surface of his work.

The seven parts are a biography of Westcott, a study of the playhouse in which the Children of St. Paul's performed, a "Calendar" of the "Presentations" which they gave, a commentary on the notebook of Michael Shaller (a verger at St. Paul's whose notebook contains entries relevant to Westcott), an introduction to The Marriage of Wit and Science which is really a study of the whole period of English drama from about 1550 to the coming of John Lyly and his glittering successors, an essay about Love's Labour's Lost, and an edition of The Marriage of Wit and Science (one of the two or three extant plays which might have been performed at St. Paul's in Westcott's time there).

The biography of Westcott is by no means the complete work which Prof. Lennam probably meant it to be, nor is the study of the playhouse. The "Calendar of Presentations" gives one pause in one significant instance. The edition of The Marriage of Wit and Science is flawed by some awkward methods and seems studiously to fall between all the stools of editorial practice. Yet Prof. Lennam's book is quite valuable and even at its shakiest never less than useful. The flaws in the edition, for example, amount to a rather thick layer of cosmetics the face behind which is good. 
For the biography, Prof. Lennam worked diligently among records in Somerset and Devon, those at St. Paul's in London, and the wills of the Prerogative Court of Canterbury. At the Public Record Office, however, he often trusted to his predecessors, mainly H.N. Hillebrand and Arthur Brown. He reviewed the documents of which they wrote, but he scouted out few fresh ones. As a result, he has given us many new bits of information about Westcott and his family, but he has missed more, and much of what he has missed is probably more important than that which he has found.

He knew nothing of Westcott's parents, for example. He should have found that Westcott's mother was Joan and that his father had died by about 1536, when his mother was the wife of a step-father, John Hammond, or Hamon, who must have been a man of means and who died in October, 1558. Joan did not remarry again and died in 1575 , leaving to her son, Sebastian, "all her goods Chattells and Debts whatsoeuer moueable and vnmoueable ... to dispose the same at his free will and pleasure." She made her will orally on March 20, "being sicke in bodie yet perfitt of mynde and memorie," and Sebastian proved it on April 4. She simply declared in a sentence or two that, in effect, Sebastian should settle her affairs. She mentioned no one else. Her son, Robert Westcott, was present, as were Elizabeth Westcott (perhaps the more or less estranged wife of her son, Philip, who was abroad) and a Robert White, but Sebastian was not. ${ }^{1}$ This will might have caused Robert Westcott to challenge Sebastian's will of 1582, thinking, perhaps, that Sebastian should have bequeathed him more of their mother's goods.

Sebastian Westcott's mother must have been a formidable and eventually ancient lady. In about 1536, she and her last husband, Hammond, bought a lease on an estate called Tetton in the parish of Kingston St. Mary just north of Taunton in Somerset. The lease was to run for as long as she, her husband, or a daughter, Jacquet, lived. The deal was probably a way of killing two birds with one stone - providing Joan and her husband with a suitable residence for life and Jacquet one thereafter. The place comprised a house and some 120 acres of arable land, moor, and pasture in the foothills of the Quantocks. The estate is still there, though the present house is an 18th century one. It was and is the largest and finest estate in a prosperous parish. Jacquet's husband, Robert Goodenowe, described her as the daughter of Joan and Hammond ("father \& mother of the sayd Jackett"), by which he probably meant just that, because Hammond and Joan had, in effect, settled an estate on her, but he could have meant that she was Joan's daughter by her Westcott husband, or Hammond's daughter by a former wife, Jacquet, in any event, was probably a child when her parents, or 
step-parents, leased Tetton, for she did not marry Goodenowe until 1548 or 1549.2

When that marriage took place, it occurred to Hammond that Jacquet and her husband would demand a half interest in Tetton, because the lease was in Jacquet's name as well as those of John and Joan Hammond. Hammond must have been a tractable man, for, according to Goodenowe, he simply arranged without being asked that the Goodenowes would have a half interest as long as he lived. When Hammond died in 1558 , however, his widow, Joan, was not so tractable. She claimed and took the whole place, and in January, 1567, despite divers gentle entreaties, as Goodenowe complained, she "yett styll dothe occupie \& enioye the same." She argued that Hammond's arrangement ended with his death, and she refused to make one like it. Goodenowe said that she meant "to defeate \& defraude" him and his wife "of all the premysses for ever contrarie to all lawe right equitie \& good conscyence." So in January, 1567, the Goodenowes sued her in Chancery for a half interest in Tetton. She was probably still at Tetton when she died, because she is said in her will to be of Kingston; and the estate probably went quietly to Jacquet then, because Joan did not mention it in her will and Goodenowe was of Kingston when he died in 1580, having been of St. Decumans (Watchet) in $1567 .{ }^{3}$ Moreover, he did not sue Joan's executor, Sebastian Westcott, for it.

Hammond was also generous to two other of Joan's children, William and Philip Westcott. In the summer of 1546, he bought for them the reversion of a piece of land called Christian's Quarter in Cheddon Fitzpaine for 20 nobles (£6.13s.3d.). Cheddon is the humbler parish which adjoins Kingston St. Mary on the east. At the same time he also bought the reversion of a cottage in Cheddon for a woman whose Christian name was Christian and who by 1560 was the wife of Richard Budge. Like Jacquet, she may have been a daughter of his, or of Joan's, or of them both. William and Philip may have been minors at the time, as their brother Robert was, for that would account for Hammond's part in the purchase. In any event, Hammond bought the reversion by a negotiation with the officials of the manor of Cheddon, paid his money in three installments, and received his deed. But the custom of the manor was that such negotiations should be carried out at a meeting of the manorial court. In 1546, the King was lord of the manor and later a Mr. Lodge, neither of whom took an interest in the matter. But eventually the lord was William Clyfton, and he set about annulling the purchase. The result was, needless to say, a series of legal maneuvres: a decision in the memorial court in 1556 that the purchase was illegal, and then, after the reversion had fallen in at the death in 1558 of the former owner, ${ }^{4}$ at least three lawsuits in London. 
Hammond did his best to protect the interests of his step-children, but their mother took a more judicial view. When Hammond lay dying in October or so, 1558, presumably at Tetton, he sent for his other step-son in the vicinity, Robert Westcott. In the presence of John Hayward, the vicar of Nether Stowey in Somerset, Hammond explained how he had bought the reversion of the land in Cheddon and why he thought the purchase legal. Then he "requyred" Robert "to depose the same at any tyme that he shuld be called therto as the said Hamon wold haue done yf he had lyved," and Robert did just that in defense of his brothers in 1560. Joan Hammond, however, acted rather differently a few months later. She did not jump to accept the accounts of her husband and children, perhaps because Clyfton was important locally. In the spring of 1559 , she summoned Thomas Dudrydge of Kingston, James Chapman of Cheddon, and Robert White (who eventually attended her dying) "to her house of Tetton" and in the presence of the other two required Chapman "to declare the trothe what he could saye concerning the Land in varyance betweene $\mathrm{M}^{\mathrm{r}}$ Clyfton and her said sonnes." Chapman had been reeve of Cheddon when Hammond had bought the reversion. He had received one of the installments of the purchase price and delivered the deed to Hammond. Chapman explained the matter much as Hammond had done to his step-son. ${ }^{5}$

William and Philip Westcott must not have got possession of their piece of land when the former owner died, for they sued Clyfton for possession early in 1560 in the Court of Requests in London. At the summons of that court, twelve men from Kingston, Cheddon, and elsewhere in Somerset, including Robert Westcott, trooped to Ilminster to testify on April 10. Their statements are all that survive of that lawsuit. ${ }^{6}$ The Westcotts must have lost the case, for they were soon suing Clyfton again in the Star Chamber, ${ }^{7}$ where they must also have lost, for, William and Clyfton both dead, Philip sued Clyfton's widow yet again in the mid-1570's in Chancery. ${ }^{8}$ Because Philip was out of the country at the time, the other Westcott brother, Sebastian, seems to have been the active force behind this third lawsuit. ${ }^{9}$ C.J. Sisson found the surviving fragment of it, and Prof. Lennam, therefore, took account of it (p. 52).

Sebastian Westcott wrote in his will that he was born in Chulmleigh in Devon, and he left the poor of Chulmleigh $£ 3$. He also left the poor of Crediton in Devon $£ 2.10$ s., those of Taunton in Somerset $£ 2$, and those of Kingston St. Mary $5 \mathrm{~s} .{ }^{10}$ In a document of 1540-42, after the dissolution of the monasteries and friaries, a William and Sebastian Westcott appear as what Prof. Lennam called "stipendiary priests receiving pensions in 1540," ex-monks, that is, Sebastian "employed" by the church wardens of Chulmleigh and William by the rector of 


\section{2 / Renaissance and Reformation}

Warkleigh nearby. Moreover, a William Westcott had been ordained deacon in the Diocese of Exeter in 1522. These pieces of information prompted Prof. Lennam to suggest that Sebastian was born about 1515 and became a priest, and that William the deacon, William the exreligious, and Sebastian's brother, William, were all the same person. He guessed that Sebastian received his training in music at the Collegiate Church of Crediton and was priest in charge of music there when the place was dissolved, after which he worked for a time as a curate in his birthplace and then made his way to London, stopping for a time with relatives in Kingston St. Mary near Taunton (pp. 10-12).

Because of the other things which we now know about Sebastian's family, however, and can notice about the dissolution of the monasteries and the document of 1540-42, Prof. Lennam's scheme seems wrong in some ways and incomplete in others. At the least, he probably has Sebastian born too early, and he must be wrong to make William the deacon, William the ex-religious, and William Sebastian's brother all the same person. He is probably wrong, too, to make Sebastian a priest.

Joan and her Westcott husband probably settled in Chulmleigh, where there were plenty of other Westcotts. After Westcott's death and her marriage to Hammond, a Somerset man, she evidently moved all her children except the two oldest with her to Somerset, where eventually, if not at once, she and Hammond set themselves up rather grandly at Tetton in Kingston. Thus all her children except Sebastian and George became Somerset people, as she did herself, belonging to the parish of Kingston or to its neighbour, Cheddon Fitzpaine. William was buried at Cheddon. William and Philip aspired to own land there. Philip's wife seems to have been in Kingston when her mother-in-law died there. Robert described himself in 1560 as a weaver of Kingston (and hence was probably neither of the Robert Westcotts whose wills Prof. Lennam found [p. 7] ). ${ }^{11}$ Jacquet and her husband set themselves up at St. Decumans in Somerset, 14 or 15 miles north under the western edge of the Quantocks, and finished, probably, at Tetton.

Joan Westcott obviously had no more Westcott children after 1536 or 1537 when as the wife of her last husband, Hammond, she joined in the lease of Tetton. Hence Sebastian, George, William, Philip, and Robert Westcott were all born before then, and so was Jacquet, whether she was a Westcott or a Hammond, for her name was included in the lease. We have a reasonably good date for the birth of only one of these children, Robert, in 1530, for in April, 1560, he gave his age as 30 "or therabout."12 We know when three or four others were married: Jacquet, according to her husband, in 1548 or 1549; William and Philip both in 1562 (pp. 8-9); and the George Westcott of North Molton in Devon (whom Prof. Lennam thinks Sebastian's brother) also in the 
1560 's. ${ }^{13}$ Jacquet was not an old woman when she married, because she had at least six children thereafter. William and George could not have been absolutely ancient, either, because each had at least four children after marrying. Jacquet may have been Joan's and Hammond's child (hence younger than all the Westcott children) and was probably a minor in 1536 or 1537 , when her parents (step or otherwsie) leased Tetton. William and Philip were probably minors in 1546, for their step-father bought the reversion of land in Cheddon for them, not the land outright.

For William to have been made a deacon in 1522, he would have to have been born by about 1498 . His mother, therefore, would have had at least 32 child-bearing years and died at some 95 years, and he would have married at 64 years and had four children after. It is all possible but hardly likely and not necessary. Prof. Lennam probably has Sebastian's birth in 1515 so that he could be at the canonical age of 24 or 25 for ordination as a priest by 1540 . If he was, however, he was born many years before his brothers and his sister. That, too, is possible but neither likely nor necessary.

Prof. Lennam did not notice a crucial distinction in the document of 1540-42, and neither he nor its finder inquired into why the document was written and hence what it is supposed to list and mean.

According to its headnote, the document belongs to the clerical subsidy of 1540 . The act of Parliament authorizing that subsidy (cap. 23) required (section 3 ) that in each of the next two years bishops send the Exchequer a list of the "stipendary preestis" in their dioceses who had to pay the subsidy, and also the names of those "with whom they doo dwell" and from whom they "take any stipend or wages." (If the "preestis" failed to pay, those who harbored and paid them had to.) The document is the list for one of those two years which the officers of the Bishop of Exeter sent to the Exchequer. Its headnote says that it gives the names of all " $\mathrm{p}^{\mathrm{r}}$ sbitorum stipendiorum" and of those who "conducunt" them. Prof. Lennam and the finder of the document read "presbyter" and "conducere" as meaning "priest" and "to employ." But the act requires much more of both words. Obviously, "conducere" is to mean something like "to live with" or "to harbor" as well as "to employ." The word "preestis" in the third section of the Act is significantly at odds with the requirements of the first section, unless it has the widest possible meaning or is ignored. For the act taxed not only all the gradations of ordained clergy at work in the ecclesiastical establishment, but also "every other personne and personnes of whatsoever name or degree he or they be, enjoying any spirituall promotion [i.e., preferment] or other temporall possessions to the same Spirituall promotions annexed." As the officers of the 
Bishop of Exeter had to read the phrase, therefore, "stipendary preestis" meant simply "stipendiaries" who worked on the spiritual side of the diocesan effort - priests, but also such unordained people as lay vicars and vicars choral. ${ }^{14}$ The drafters of the next act of the same kind (1545, cap. 24) prevented this difficulty by adding a new section (9): "everie laye persone having anye spirituall promocion chardgeable by this Acte... shalbe chardged taxed and sett for his saide spirituall promocion with the Clergie." The lists of stipendiary priests of 154547 , that is, were explicitly to include non-priests, as those of $1540-42$ were implicitly to have done.

A "stipendiary" person, in ecclesiastical terms, finally, did not receive a pension. He did spiritual work and received regular wages for it, but he did not have one of the established positions, like a rector or vicar, and unlike persons who held such positions, his wages did not come from any of the established funds of the church, like a living. ${ }^{15}$ The act also taxed pensioned ex-monks, but called them "Preestis or other personnes Religiouse" and their payments, "yerely rentis or pensions." There were to be lists of them, too, provided not by bishops but by the Court of Augmentations in London or whoever else paid their pensions. These lists apparently no longer exist.

The document reads that the church wardens of Chulmleigh "conducunt" Sebastian Westcott, and the rector of Warkleigh "conducit" William Westcott.16 Because Sebastian could hardly live with the church wardens, they merely employed him. William was employed by the rector and perhaps lived in his rectory. Now, rectors are responsible for the priestly duties in their parishes. They hire priests to serve in their stead as curates. Church wardens, however, are responsible for the other ecclesiastical matters. They hire parish clerks, organists, choirmasters, vergers, and the like. In 1540-42, therefore, William Westcott was indeed a priest, a middle-aged one if he was also the deacon of 1522 , but he was very likely not Sebastian's brother. He could have been the William Westcott of Chulmleigh who sued Anthony Coxed some ten years later. ${ }^{17}$ Sebastian Westcott in 1540-42, however, was very likely not a priest but a vicar choral, or choirmaster, helping with the music of the church at Chulmleigh, which had once been a "college" and may still have supported a more sophisticated music than other parish churches. Sebastian (and William, too) may or may not have been ex-monks. The document, incidentally, lists 414 stipendiaries and concludes with a total, £224, presumably the tax they paid in the year of the list. The tax for each of two years was $2 \mathrm{~s}$. in the pound earned. Hence the stipendiaries earned on average about $£ 5.10 \mathrm{~s} .0 \mathrm{~d}$. each a year. 18

Sebastian was probably the eldest of the Westcott children, for his 
mother made him her heir when all her known children but William were alive. Moreover, Sebastian looked after at least two brothers and his sister: according to a friend of his, he protected Philip and advanced him money, ${ }^{19}$ and he wrote in his will of having lent Robert and Jacquet money which they had not repaid. The second child may have been George, for Sebastian mentioned him first in his will. The third may have been William and the fourth Philip (their names regularly appear in that order in the documentation about their reversion). ${ }^{20}$ The fifth may have been Robert.

One might guess, then, that Sebastian was born early in the 1520's, and that William and Philip were born after 1525 and before 1530 . Joan's Westcott husband probably died shortly after, or even before, Robert was born in 1530, and she probably married Hammond within a year or so and, if Jacquet was a Hammond, bore her very soon after.

To fetch up as vicar choral and then almoner at St. Paul's, Sebastian Westcott must have been a thoroughly trained musician. One might guess, then, that Sebastian's parents sent him in 1527 or so to the Collegiate Church of Crediton to become one of the four choristers on the strength of the place. He would have remained one until his voice broke, in about 1533. He might then have stayed on as one of the four "singing-men or lay Vicars" there, ${ }^{21}$ or informally to help with the music, like the ex-choristers whom he mentioned in his will as still a part of the musical establishment at St. Paul's in 1582. In any event, he would have learned music and much else at Crediton. Because the Collegiate Church there was not dissolved uritil 1545, being neither a monastery nor a friary, Sebastian could not have been pensioned from the place in 1540.22 If he became a religious, he would have left Crediton in about 1536 or 1537 , bound for a monastery rather than a friary, and one large enough to support a full-time musical establishment. He would have served for a year as a novice and then been tonsured and clothed at the age of 16 or 17 , a youth proceeding through the minor orders toward the priesthood, which he could never have reached. He would have served as a musician, perhaps a vicar choral, for a year or two, until his house was dissolved in 1538 or 1539 , when he would have joined the numerous ranks of pensioned ex-monks. If he did not become a religious, he simply left Crediton eventually, his training finished, and sought work as a musician.

What he would have done at Crediton as a boy and perhaps at some monastery as a more or less professional musician appears in the contract of a musician (who was not a priest) at Glastonbury Abbey, drawn up in August, 1534.23 James Renynger, "Syngyngman," agreed for his lifetime to sing and play "vpon the Organes... yn deyly seruices . . yn the Chappell of or blessid lady yn Glastyngbry .... as deyly 
matens masses yeven songs complens anteymes \& all other devyne seruices as hath ben accostomably ... songen yn the seid Chappell," moreover "to do seruice yn syngyng \& playng vpon the Organs yn the high quier of Glastyngbry yn ... suche festes \& festyval dayes as hath ben ... vsed \& accostomyd ther." He also agreed "to jnstructe and teche the sixe Chyldren ... for the Chappell of $o^{r}$ blessid lady... sufficiently laufully \& melodyously With all his dyligence in pricke songe \& descaunte," and to teach especially the two most apt so that within two years they could play "at the Organes" and within six sing and play "At the Organes deyly yn the seid Chappell of or lady \& high quier" as Renynger himself was supposed to do. The Abbott (Whiting) undertook to "fynde the seide James Renynger Clauyngcords to teche the seid two Chyldren to pley vpon." Quite likely, Sebastian Westcott had just left off being such a child at Crediton as these two at Glastonbury were. At all events. Renynger received for these services $£ 10$ a year, an annual gown, two loads of firewood, and the rent of his lodging. A clause provided that if Renynger were "taken up" to serve in the King's music, he could have his position again at Glastonbury if he returned to it within a year and a day. Renynger lived, as Whiting did not, to claim a pension. ${ }^{24}$

The only reason for thinking that Sebastian Westcott was a monk is that he was a stipendiary in 1540-42, and that many stipendiaries then were probably ex-religious who had found their way back in to spiritual work. There is no positive evidence. No Westcott appears in any of the lists which survive of pensioned ex-religious, including those for all but a few of the houses in Devon and neighbouring counties. ${ }^{25}$ The list of the house of Austin Canons at Taunton is one which survives - without a Westcott, but with a John Heywarde, the vicar of Nether Stowey in 1558? The lists for two conspicuous houses, however, do not survive, that for the most conspicuous and finest of them all in the west, Glastonbury, and that for Muchelney, both places twenty miles and less from Kingston St. Mary. ${ }^{26}$ Could Sebastian have been briefly a young colleague of James Renynger?

If Sebastian had been a monk, his pension would have been a pound or two less than that of an ordained ex-monk and probably below the cost of subsistence, in any case hardly enough to tempt a young man to retire. One of the provisos of ex-monks' pensions was that the payer of the pension could offer the ex-monk a job at an equivalent or greater sum and cancel the pension. So one next finds Sebastian Westcott in London in the King's service in 1545, a Yeoman of the Chamber, having swapped, maybe, his pension for a job. ${ }^{27} \mathrm{He}$ was, however, or would soon be, looking beyond such employment toward a career for which he had been trained and in surroundings, except for size, like 
those in which he had grown up, in the musical establishment of St. Paul's Cathedral.

On the evidence of their wills, Sebastian Westcott amassed more of this world's goods than his brother, George (if Prof. Lennam is right to make George Westcott of North Molton a brother) and both did better than their brother-in-law, Goodenowe. ${ }^{28}$ On the evidence of the lawsuit reported by Sisson and Prof. Lennam, all three did better than Philip Westcott (pp. 7, 52-53), and even he may have been better off at the end of his life than their sister, Jacquet, and brother, Robert, to both of whom Sebastian lent money. Sebastian's prosperity might argue the value put on song and drama in Elizabethan times, even in a religious setting, but it could also argue, perhaps even better, that Sebastian was indeed his father's eldest son and hence began his mature life with a bigger share of his father's possessions than any of his brothers had.

Apart from new information which one should add to Prof. Lennam's biography of Sebastian Westcott, there are a few places, all footling, in the biography where one should probably hesitate. Christopher Westcott, for example, was the son and heir of George Westcott of North Molton, hence very likely not his second son but his first (p. 8). The Elizabeth Westcott who was living in one of George Westcott's houses in Chulmleigh in 1589 certainly need not be Philip Westcott's widow, or, indeed, any widow (p. 8). The document which Prof. Lennam could not find at the P.R.O. in 1968 (E. $159 / 334 / \mathrm{m} .238^{\mathrm{V}}$ ) is there now and readily available; it says, generally, what Hillebrand reported it as saying (p. 17). Prof. Lennam argues that Westcott was living at the Almonry of St. Paul's in 1550 because he paid taxes in Castle Baynard Ward - but the Almonry is distinctly in the adjoining ward, that of Farringdon Within (p. 16). Prof. Lennam suggests on "admittedly flimsy" grounds that the playwright with whom Westcott was associated in the 1550's, and perhaps in the 1540's, John Heywood, was from the same part of Somerset as that in which so much of Westcott's family had settled, and hence that the association might not have been the result of a chance meeting in London (pp. 13-14, 16-17, 33-34). The presence of John Hayward, vicar of Nether Stowey (just over the Quantocks from Tetton), at the deathbed of Westcott's step-father might strengthen the suggestion, and so might an association in 1593 between an Andrew Westcott of Chulmleigh and John and William Heywood of North Tawton in Devon. ${ }^{29}$

$$
* \quad * \quad *
$$

The shape and whereabouts of the playhouse, or playhouses, at St. Paul's have been among the most conspicuous gaps in our know- 
ledge of the Elizabethan stage. Westcott's playhouse went out of use shortly after he died in 1582, but a playhouse also called St. Paul's was being used possibly at the very end of the century and certainly for a few years into the next. Prof. Lennam has briefly reviewed the problems and the scanty information available to resolve them, and, perhaps wisely, he has let the matter go at that. Recently, however, a former colleague of his, Prof. Reavley Gair of the University of New Brunswick, has found the "presentments" of 1598, described inaccurately and untraceably by J.P. Malcolm in 1803, and sought earnestly but in vain by Hillebrand fifty years ago. They are one of the problems which Prof. Lennam has reviewed (p. 47n.). Prof. Gair found them not at St. Paul's, where one would expect to find them, but at Guildhall. They show that in 1598 there was a "house" in the open space between the cloisters and the Chapter House and that the master of the choristers (who was responsible for the playhouse and its company) controlled the land on which it stood. Prof. Gair is convinced that this house contained both Westcott's and the later playhouse and that he has, therefore, located and unified the place at last, and, coincidentally, made this part of Prof. Lennam's book obsolete. ${ }^{30}$

Putting the playhouse in the space between the cloisters and Chapter House is not new, for G.P. Baker made the suggestion in 1907.31 Prof. Gair's contribution is to find a house there and to find that the master of the choristers controlled the area. Some striking difficulties with the idea, however, remain.

It continues possible, for example, that there were two playhouses. The only specific evidence for the location of Westcott's playhouse is a remark in an order of the Court of Aldermen of London in 1575 implying clearly that the place was within the jurisdiction of the Dean of St. Paul's and not that of the Aldermen (p. 43). All the other evidence about a playhouse at St. Paul's either obviously does or could easily belong to the later operation, as Prof. Gair's could. His evidence shows that in 1598 the area adjacent to the Chapter House had "a longe tyme byn used of the master of the Quoristers" - which may or may not take one back to Westcott's playhouse. Prof. Gair reports a remark of 1603 that the Children of St. Paul's played "in a private house of a longe tyme keepte used and accustomede for that purpose," which does not necessarily get one back to Westcott, either.

But it must be likely, even so, that there was just one playhouse. More to the point is whether Prof. Gair has necessarily found a playhouse at all. There are, sadly, at least three good reasons that he has not, or, at least, has not yet. The first has to do with the amount of space available around the Chapter House. The Chapter House was octagonal and rested well above the ground on four massive buttresses, 
between which was an octagonal crypt. This structure was surrounded by a square one made up on all four sides of a sizable cloister at ground level and another of like size above that one. The whole lay in the angle formed by the nave and south transept of the Cathedral, and on its two other sides was a high stone wall. Between the cloisters and the Chapter House was a small open space all around. A most accurate draughtsman, Hollar, drew a picture of the place which Dugdale printed in 1658, and Baker reprinted in 1907 and Chambers, as the frontispiece of the second volume of his Elizabethan Stage, in 1923. Prof. Lennam suggests how little space was between the cloisters and the buttresses (p. 45), and Prof. Gair's drawing seems to show that at the very most, the house there could have had internal measurements of only about 20 feet by 20 feet. Even a small playhouse would have to be bigger than that. If the house was where Prof. Gair reasonably puts it, in the northwest corner of the area, it was at the rear left of the place as Hollar drew it. One can arrive at one's own conclusions by reaching for Chambers' second volume. 32

Prof. Gair's "presentments" show that in 1598 the master of the choristers probably controlled the upper cloister and certainly controlled, "used" (and had done so for a long time), the lower one and the space between it and the Chapter House. They also show that there was a "house" in part of this space, built by Mr. Laydon, a minor canon (as the master of the choristers had not been since before Westcott's time [p. 20n.]), and standing close to the Chapter House wall, presumably the buttresses. The "presentments," however, do not say that the master of the choristers controlled the house, just the land on which it stood; nor do they say "how long Mr. Laydon's house had existed, just that the master of the choristers had controlled the land for a long time. Even if the house dated back to the early 1570 's, as Westcott's playhouse did, the master of the choristers obviously leased the land to Mr. Laydon so that he could build the house, and the master of the choristers could have leased land and house to others when Laydon's lease on the land was up. He did rent out the lower cloister, as Prof. Gair shows, to trunk-makers. When one controls land on which a house stands, one does not necessarily also control the house. The "presentments," finally, do not even hint that the house could be used as a playhouse. The master of the choristers, as Prof. Lennam (pp. 45-47) pointed out, actually controlled at least four other houses in and just out of the churchyard, and Prof. Gair's evidence adds nine sheds to this muster, as well as the cloisters and land around the Chapter House. That the master of the choristers controlled a place, obviously, does not make it a playhouse.

Prof. Gair needs evidence showing that the playhouse was near the 
Chapter House, or at least, as he says, "inside the locked area of the Cathedral," where, among many other structures, the cloisters and Chapter House were. Two matters noted by Chambers would seem useful. One is a remark by Richard Flecknoe, printed in 1664, that the playhouse was "behinde the Convocation-house" (i.e., the Chapter House). Prof. Gair is, however, rightly dissatisfied with it, as Chambers was. What "behinde" means is a problem and so is Flecknoe's reliability. He was probably born after the playhouse ceased to function and, in any case, made the remark some 60 years later "in," as Chambers wrote, "a passage dealing (inaccurately) with Jacobean rather than Elizabethan conditions." The other matter is a note apparently written by William Percy, the author of six plays, all, it seems, unperformed on the professional stage. The note instructs the master of choristers at St. Paul's how he might shorten Percy's plays should he produce them, because, according to Percy, plays at St. Paul's could last only two hours, the children being unable to begin before 4:00 after prayers, and the gates of the Cathedral precinct (within which, by implication, the playhouse was) shutting at 6:00. Prof. Gair relies on this note several times, but it is at least as dubious as Flecknoe's remark. Prof. Lennam, curiously, does not even mention the note.

J.P. Collier first reported it, somewhat inaccurately, in his History of English Dramatic Poetry (London, 1831), III, 377, and Chambers repeated it as Collier had it. Collier said that he found the note at the end of the play, Necromantes, in a manuscript lent him by his friend, Joseph Haslewood. Percy transcribed his plays three times in manuscripts which survive, all six plays in each of two manuscripts and three plays in another. One of the manuscripts with all the plays and that with only three are in the collection of the Duke of Northumberland at Alnwick Castle. The other with all the plays is at the Huntington Library, and that is the manuscript which Haslewood once owned. The note is where Collier said it was and nowhere else in any of the manuscripts. Necromantes is in only the two manuscripts with all the plays.

At least one writer has suspected that the note is one of Collier's forgeries, because Collier had the manuscript by him for a time and announced the note in that first scene of his crimes, his History. If Collier forged the note, however, he made all the letters exactly as the writer of the rest of the manuscript habitually made the same letters, and he also mistranscribed its first clause to create a sophistication which destroys the credibility of the note. The note reads,

\section{A Note}

To the Master of children of Powles

Memorandum that if any of the fiue and foremost of these Pastoralls and Comaedyes conteyned in this volume shall but ouereach in lengh (The 
children not to begin before Foure after Prayers And the gates of Powles shutting at six) the Tyme of supper, that then in tyme and place conuenient, you do let passe some of the songs and make the consort the shorter, For I suppose these plaies be somewhat too long for that Place. Howsoeuer on your own Experience and at your best direction be it. Farewell to you all.

\section{W.P. Esq. 33}

Collier read "fine" for "fiue," which may be more poetic, but which fatally misidentifies the sixth play, Necromantes. The first five plays were written (according to Percy in all his transcriptions of them) between 1601 and 1603, when the playhouse at St. Paul's was open. Moreover, Percy added notes to them all explaining how they could be performed at St. Paul's. Necromantes, however (as he also said in both manuscripts), belongs to 1632 , some 25 years after the demise of the playhouse. He added no notes to it about St. Paul's and at the end in both copies wrote, "For Actors onely," by which he meant for companies of men rather than of boys as at St. Paul's. From what ought to be Collier's point of view if he forged the note, therefore, to read "fine" is to put Necromantes where it could not be.

The trouble with the note is its date, its writer's reliability, and, above all, what it actually says. Percy dated the Huntington manuscript as 1647, the year before that in which he died (he dated the complete manuscript at Alnwick as 1646 and the incomplete one as 1644). Did he write the note de novo in 1647 ? Or had he written one like it long before which he overlooked in 1644, 1646, and when he came to the right place for it in 1647 (after the fifth play) - and which he then rewrote so as to exclude Necromantes? Either way, in his note he told a company defunct for 40 years how it might perform his plays, yet realized that the company could not perform Necromantes because he wrote that play in 1632, when the company had been defunct for 25 years. The confusion is radical, and it does not inspire confidence, especially when we find him described in 1638 as living "obscurely in Oxford" and drinking "nothing but ale," at his death as "an aged Bachelour" who "had lived a melancholy \& retired life" at Oxford "many yeares," and, in his modern biography, as declining in to "senile decay." That in 1644, 1646, and 1647 he added stage directions to five plays explaining how St. Paul's and sometimes other extinct children's companies might perform them also suggests that he was confused, but his confusion here need not be so radical as that involving Necromantes as well.

The note, finally, does not necessarily allude to the playhouse at all. The remark about shutting the gates at 6:00, supper time, could mean that the performers had to be inside the Cathedral precinct when the gates shut and their supper began. They could have performed any- 
where inside or just outside the precinct. We could still be, that is, where Prof. Lennam left us, with four sizeable structures controlled by the master of the choristers inside and just outside the precinct, any of which could have embraced the playhouse.

Despite the confusions of his old age, Percy's manuscripts might provide useful information about the stage and staging at St. Paul's. V.E. Albright, G.F. Reynolds, Chambers, Hillebrand, M.H. Dodds, and others have nibbled around the edges of them, but no one, including Profs. Gair and Lennam, has bitten determinedly into them. ${ }^{34}$ The reasons are not far to seek. The plays are weak, Percy's hand is often difficult and made more so by his many afterthoughts, and relationships among the manuscripts are complex. Moreover, his many hints about the stage and staging at St. Paul's would require much steady thought to get out of them a consistent and rational scheme.

$* \quad * \quad *$

In his "Calendar of Presentations," Prof. Lennam goes carefully through the surviving evidence of performances by Westcott's company, but he really does strike a forgery and not because it is submerged. It had been brilliantly documented by H.E.D. Blakiston in 1896 and duly signalled by both Chambers and Hillebrand. ${ }^{35}$ Prof. Lennam, however, chose to ignore these warnings and to accept instead and without much investigation or even much argument J.T. Murray's thoughtless signs that all was deep water. He managed also to bungle his citation of Murray as "I, 286" rather than I, 325; II, 286 (p. 56). But no matter, for the whole entry about a performance of December 4, 1554, or April, 1557 (Prof. Lennam's no. 4), should be lined out. It took place only in the mind of Thomas Warton, who as he was finding Chatterton's "discoveries" to be forgeries in the 1770's tried some forgeries himself which have been a good deal more successful than poor Chatterton's.

The reasons for the two dates are instructive, and Blakiston did not explain. ${ }^{36}$ Warton first (1778) wrote that "In the year 1554, while the princess Elizabeth resided at Hatfield-house in Hertfordshire, under the custody of Sir Thomas Pope," Queen Mary visited her and after supper on the second day, the two saw a play performed by the boys of St. Paul's. In a footnote, he added, "Who perhaps performed the play of Holophernes, the same year, after a greate and rich maskinge and banquet, given by sir Thomas Pope to the princess, in the grete hall at Hatfelde." But during the next two years Warton saw several yawning holes in his story. Sir Thomas Pope did not become the Princess's guardian until July, 1556, and she did not take up residence at Hatfield 
until about the same time. Moreover, he had already (in 1772) given the play of Holophernes - another invention - as taking place at Shrovetide in 1556. So in 1780 Warton made some adjustments. He dated the play at Hatfield as April, 1557, and divorced from it the play of Holophernes, which went back to being at Shrovetide, 1556.37 He did not trouble to adjust also his supposed sources. Again, however, the facts intervene, for Pope seems to have ceased being guardian to the Princess late in 1556 , of which Warton did not know.

* $\quad * \quad *$

Prof. Lennam's edition of The Marriage of Wit and Science is conservative, sensible, and careful. One looks hard to find substantive objections, and when one finds them they prove trivial. Prof. Lennam reads "then," for example, at line 408 when he should read "then," and when Nature speaks of "an other Lord above" (line 97), Prof. Lennam tells us that she means Jove (p. 178), even though she goes on, "That hath receaved unto his disposition/The soule of man." At line 1438 he rightly declines to follow his predecessors in emending "vppe on" to "upon" because he thinks that the expression means, in effect, "up at" rather than "on," but he forgets scansion, which clinches his case. The writer regularly put the stress on the second syllable of "upon," and here he put it on "vppe."

If the substantive aspects of the edition seem sound, however, some of the procedural ones are annoying, unnecessary, and expensive. He constantly over-explains. He assures us seven times that "to speed" means "to prosper" and the like 38 (but misses an eighth chance at line 1048). He tells us that "Be ruled" is "a common expression" and that "Tushe" is "an extremely common exclamation." We discover that "flym flam" is "nonsense, idle talk," that "the marke that he would hit" means his "target," that "fittlye" means "aptly, skilfully," that "snorting" means "sleeping heavily," and so on. 39 But worse is his awkward marriage with modernization.

He silently modernizes all punctuation. He also modernizes much spelling and has two ways of doing it. Some words appear in modern spelling in his text with the original spelling at the bottom of the page. Other words appear in the original spelling in his text, but have the modern spelling in the explanatory notes. Why one word is modernized one way and a second the other is not very clear, or why a third is not modernized at all, but one thing is quite clear: much of this modernizing amounts to further over-explaining. Thus of the words modernized in the text with the original spelling at the bottom of the page, there are "do" for "doe," "good will" for "good wil," "Will" for 
"Wyll," "Nature's" for "Natures," "th'advantage" for "thaduantage," "Lady's" for "Ladies," and even "odd" for "od." And of the words not modernized in the text but modernized in the explanatory notes are "inowe" for "enough," "fraght" for "fraught," "marchant" for "merchant," "seene" for "seen," "ketch" for "catch," "durte" for "dirt," and "cloobe" for "club." Yet words like "Causles" for "causeless," "clyme" for "climb," and "slouth" for "sloth" are not modernized anywhere. ${ }^{40}$ These flabby methods tend to persuade the hasty reader that the edition is less reliable than it really is.

\section{University of Saskatchewan}

\section{Notes}

1 PROB.11/57/f.98v.

2 C.3/77/74, a lawsuit of January, 1567, in which Robert Goodenowe said that the Hammonds had leased Tetton "aboute thirtie yeres nowe paste" and that he and Jacquet had married "aboute eightene yeres now paste." He also said that the Hammonds had bought the lease from John Hewshe, a person of whose name died in February, 1553, having said in his will (PROB.11/36/f.19-19v) that he wanted to be buried at St. Decumans (where Robert and Jacquet lived for a time) and had a brother-in-law, Humphrey Walrond (Robert's lawyer in the lawsuit was named Walrond). Moreover, a Humphrey Huysshe who was active in lawsuits for about 40 years until the 1550's had a wife, Jacquet, and owned lands in Swimbridge, near Chulmleigh in Devon (C.1/416/15, 16; /520/25-29;/1505/41).

3 The lawsuit survives only in the Goodenowes' complaint, dated January 23, 1567: C.3/77/74. Inexplicably, Prof. Lennam (p. 6) gives Goodenowe's death as 1579 . His widow proved his will on May 10, 1580: PROB.11/62/f.152-52 .

4 Req.2/66/16. James Chapman said in April, 1560, that the former owner, William Lawrence, died "two yeres past or more" (no. 2), and John Hill agreed with him (no. 1-3). Chapman also said that the manorial court took its decision after Lawrence had died (no. 13), but here Hill disagreed (no. 13). Richard God (nos. 3,4) said that it took its decision "about a two yeres before the death of quene Mary," i.e., in 1556, and seven men (John Pope, John Wyrall, Richard Marshefyld, John Mogridge, John Lynge, Richard Coke, and William Hare) agreed with him. The interrogatories (which are missing) evidently also read that the manorial court took its decision before Lawrence died (see Chapman's and Hill's answers to no. 13).

5 Req.2/66/16, the depositions of Chapman, Robert Westcott, and Dudrydge, April 10, 1560. Westcott testified that Hammond, "his father yn lawe," was on his deathbed "about one yere and half past," and Dudrydge that the episode at Tetton took place "about a yere past." Robert Goodenowe said in January, 1567, that Hammond had died "aboute ten yeres nowe paste" (C.3/77/74).

6 Req.2/66/16.

7 St.Ch.2/34/41, a brief and undated rebuttal by Clyfton to a surrejoinder by the Westcotts. The document has been filed as belonging to the time of Henry VIII, but obviously belongs instead to the 1560 's.

8 C.24/127/13, 19 [now folded together and 10th in the box] : interrogatories and two depositions for the widow Clyfton (Robert Smyth and Thomas Cocke), and interrogatories and two depositions for Westcott (Nicholas Brystow and Antony Morres). The property is not specifically mentioned, but Philip argued that he should be allowed to hold property in the manor of Cheddon though abroad. The widow Clyfton seems to have argued that Philip 
would have been an unsuitable copyholder, being not only wilfully absent but a Papist, a debtor, and an immoral man who had a second family in Barbary. Neither of her witnesses, however, bore her out, and Philip's established that he could not return to England for reasons beyond his control. One of Philip's interrogatories asked about Sebastian's reputation and the result was two encomiums, one from a man who said that he had known Sebastian for 40 years (Brystow - a person of the name was clerk of the Wardrobe early in the 1540's and later of the Revels: E.405/112/f.20v $47 ; / 116 / f .5^{v}, 30^{v}$, etc.), who "never ... knew hym but of very honest report and conversacion, And so ... he is accepted reputed and taken both of the [e]state of this Realme the nobilite and generally of all men ... as honest a man and of as good report and honest conversacion as iij of his degree $w^{t_{\text {in }}}$ the Realme" (no. 11). See also Sisson's note, RES, 19 (1943), 204-05.

9 One of Philip's interrogatories (no. 4) asked if Sebastian was author of the lawsuit, probably because the widow Clyfton had said so in her reply to the bill; Brystow declined to answer, and Morres began by saying that he did not know, then said that Sebastian was acting only as Philip's agent, and finally had the whole answer stroked out.

10 PROB. $11 / 64 /$ f. $99-100^{v}$.

11 Req. $2 / 66 / 16$.

12 Ibid.

13 The reasons for thinking that this George Westcott was Sebastian's brother are that this George owned lands in Chulmleigh in Devon (where Sebastian was born) and named one daughter Jacquet and another Joan. This George was probably married in the 1560 's because when he made his will in 1589 both his daughters were unmarried but nearing marriageable age (they were to receive their portions within three years of his death), his second son, John, had a child, and his eldest, Christopher, apparently did not. See PROB.11/82.f.384-85.

14 The word the officers chose was probably nice in 1540-42: not "sacerdos," which meant only ordained priests, nor "clericus," which by itself meant only unordained people, but "presbyter," which reformers were insisting should mean what it had anciently meant, anybody responsible for the work of a church, elders of a church.

15 "Stipendarie Prests" are defined in the two acts of Parliament which dissolved colleges, free chapels, chantries, and such stipendiary priests as were paid out of perpetual funds money, that is, appointed by a donor to be paid out of his estates forever (see esp. sect. 1 of both acts: 1545 , cap. $4 ; 1547$, cap. 14 ).

16 E.344/19/15/f.1 $1^{\mathrm{v}}, 11,11^{\mathrm{v}}$, reported by Frances Rose-Troup in Devon and Cornwall Notes and Queries, 17 (1932), 81-82, 285. She also read "stipendiary" to mean pensioner.

17 C.1/1279/26, the bill only, addressed to Sir Richard Rich, hence filed between October, 1548, and December, 1551. This William's grandfather was Peter Westcott, his father, John, and his elder brother another John.

18 C. $24 / 127 /[10$ th in the box ], esp. Morres, nos. 1, 9. Sebastian advanced $£ .66 .13 \mathrm{~s} .4 \mathrm{~d}$.

19 People who earned an annual wage which was not a "perpetuity" were also taxed. They paid a flat rate of half a mark a year for two years. The act does not require a list of these people, and the document of 1540-42 could not be of them for another reason: the total is wrong. That number of people at half a mark each should yield $£ 138.16 \mathrm{~s} .8 \mathrm{~d}$. in one year or $£ 277.13$ s.4d. in two.

20 Req.2/66/16, in the heading and in the testimonies of James Chapman (no. 4), John Hill (no. 4), and Robert Westcott.

21 William Dugdale, Monasticon Anglicanum, ed. John Caley, Henry Ellis, Bulkeley Bandinel (London, 1830), VI, 1450-51.

22 Colleges, chantries, and free chapels were dissolved by acts of Parliament of late 1545 (cap. 4) and 1547 (cap. 14). The College at Crediton, however, seems to have been dissolved in the spring of 1545 , for one of its pensioners was entitled to the first half yearly installment of his pension at Michaelmas, 1545 (E.315/254/f. $32^{\mathrm{V}}$ ). No one from Crediton appears on the list of persons in Devon pensioned in 1548 according to the act of 1547 (Rose-Troup, pp. 334-36, 381-84). 
23 Prof. Lennam also offered the contract of a musician to show what Sebastian Westcott may have done (p. 11), but that musician worked at a cathedral, not a house of religious, and one very remote from Devon; his contract, moreover, was drawn up before Sebastian was born. Still, the duties seem similar and the pay was about the same.

24 E.135/2/31. Renynger's work with the children was to be particularly under the supervision of the Abbot. He did not get a pension at the Dissolution, being, possibly, in the Royal service at the time. Eventually, in about 1568 , he presented his contract to the Court of Augmentations (which is why the contract survives) and received a pension of $£ 2$ a year back-dated three years - as a note on the back reads.

25 No comprehensive list survives of religious at the Dissolution, but various documents do which give the names of many but not of a Westcott. None appears in the list of ex-religious paid pensions out of monastic lands or among the surviving warrants for pensions (49th Report of the Deputy Keeper of the Public Records). None is in the lists of pensioners which survive for many houses (Cal. of the Letters and Papers Foreign and Domestic, 1538-f.), or in Cardinal Pole's list of ex-religious being paid pensions in 1555-56 (E.164/31), or in the list of pensioners in Devon who had died by 1570 (Rose-Troup, Devon and Cornwall Notes and Queries, 18 [1933], 45-48). No Westcott signed one of the surviving surrenders (8th Report of the Deputy Keeper), or was paid at the Court of Augmentations in London (E.315/248-62), or, so far as I can find, signed one of the many surviving receipts (E.314/26-32).

26 Twenty-five monks of Glastonbury appear in Cardinal Pole's list of 1555-56, including no Westcott; but if Sebastian had one, he would probably have given up his pension by 1545 .

27 For the pensions and later careers of ex-religious, see Dom David Knowles, Religious Orders in England (London, 1959), III, 402-17. Some "lay brothers" from Sheen, however, had bigger pensions than some "monks" from there (E.315/249/f.24), and how an ex-monk could swap a pension is an even murkier matter than much else about the pensions. The first act concerned with the dissolving of religious houses (1535-36, cap. 28) provided pensions only for heads of houses and had no provision for swapping them. The act establishing the Court of Augmentations (cap. 27) and that which confirmed all that had been done and would be (1539, cap. 13) did not mention pensions at all. The act of 1545 (cap. 14) dissolving colleges and the like finally described pensions and swapping them, but provided only that a pension would cease if the King gave the pensioner a benefice or other spiritual preferment of greater value (sect. 11). Yet pensions were obviously assigned in great numbers, regularly paid, and, it seems, not infrequently swapped, though without sanction of Parliament.

28 He left three daughters $£ 5$ each and two others and his son household goods only; two men, he said, owed him $£ 7.6 \mathrm{~s} .8 \mathrm{~d}$., but he owed 12 others $£ 21.12 \mathrm{~s} .0 \mathrm{~d}$.: PROB.11/62/f.152-52 $\mathrm{V}$.

29 St.Ch.5/B.98/36; /B.44/10. All three were servants of Lord Edward Seymour. The two Heywoods signed their names so.

30 Prof. Gair made his announcement in a paper delivered at the Waterloo Conference of 1975. It will soon be published among the papers of the Conference in The Elizabethan Theatre VI (Toronto: Macmillan). I am grateful to him for a copy of the relevant part of his paper.

31 The Development of Shakespeare as a Dramatist, pp. 45-46, 95, 115.

32 Hollar also drew the Chapter House precinct from outside the stone wall, once from the south and once from the west. Prof. Lennam printed both drawings (p. 28), which do not suggest much room, either.

33 HM 4 (between two sets of alterations at the end of the play, the second dated 1636 in both mss.); Chambers, The Elizabethan Stage (London, 1923), II, 21. The mss. at Alnwick (508, 509) are part of the British Manuscripts Project (F391-92). I am indebted to his Grace for permission to see the B.M. microfilm of his mss. (reel 324) and to the Huntington for permission to publish part of theirs. Hillebrand wrote of both Percy and the ms. at the Huntington, "William Percy: an Elizabethan Amateur," HLQ, 1 (1937-38), no. 4, 391-416. Sydney Race thought the note a forgery: $N \& Q$, Jan. 7, 21, Aug. 5, 1950. In his remark about the Chapter House, Flecknoe also mentioned that the children performed "after Vespers" (Chambers, II, 16n.; IV, 369-70). 
34 Chambers, III, 136-38, 464-65; Albright, "Two of Percy's Plays as Proof of the Elizabethan Stage," MP, 11 (1913), 237-46; Reynolds, "William Percy and his Plays," MP, 12 (1914), 241-60; Hillebrand, The Child Actors (Urbana, 1926), pp. 217-19; Dodds, $N \& Q$, Oct. 3, 10, 1931 , and "A Forrest Traegedy in Vacunium," $M L R, 40$ (1945), 246-58, etc.

35 Blakiston, "Thomas Warton and Machyn's Diary," EHR, 11 (1896), 282-300; Chambers, II, 13, and The Mediaeval Stage (London, 1903), II, 196; Hillebrand, p. 124n.; even D.N.B. has a warning: "Sir Thos. Pope," which Blakiston wrote.

36 Prof. Lennam accepted the story because of this change in dates. Not having read Blakiston carefully, Lennam thought that he had rejected only a performance of 1554 , and noting that Murray gave the date as 1557 , he assumed that Murray had an independent and reliable source which Blakiston had not taken into account. Murray; however, had not read Blakiston carefully, either, and simply accepted the story as he found it in John Nichols, Progresses... of Queen Elizabeth (London, 1823), I. 17, who had uncritically accepted Warton's final version of it.

37 Life of Sir Thomas Pope (London, 1772), first edn., pp. 84-85; History of English Poetry (London, 1778), first edn., II, $391-92$ (and for Chatterton, 153-64); Life of Sir Thomas Pope (London, 1780), 2nd edn., pp. 86-87, 89. In 1780 he also dropped the specific reference to Sir Thomas Pope, though he implied one. In his section on Chatterton, he suggested the forger's motive: "the pleasure of deceiving the world, a motive which, in many minds, operates more powerfully than the hopes of gain ... the private enjoyment of the success of his invention and dexterity." But, he concluded, "there is a more solid satisfaction resulting from the detection of artifice and imposture" (pp. 158, 164).

38 Lines 153, 520, 674, 715, 1114, 1300, 1453.

39 Lines $208,242,284,460,1156,1416$. He misses a chance to deal similarly with "marke" at line 621 .

40 Lines $84,177,186,624,662,1009,1392 ; 47,141,1316,1399,1463,1482,1486$; 170, $204,1029$. 